\title{
CRITICAL-THINKING ASSESSMENT TABLE: A NOVEL STRATEGY TO FOSTER STUDENTS' CRITICAL THINKING DISPOSITIONS
}

\author{
Ahmad Sulaiman \\ College of Education, Psychology and Social Work, Flinders University, Australia \\ sulaiman_amdamin@outlook.com
}

\begin{abstract}
Abstrak. Disposisi berfikir-kritis adalah aspek penting dalam diri siswa yang mendorong mereka untuk berfikir-kritis baik dalam kehidupan akademik dan sehari-hari. Sayangnya, para peneliti menaruh perhatian yang begitu kecil kepada disposisi berfikir kritis. Penelitian ini bertujuan untuk mengembangkan dan menguji coba suatu strategi baru untuk menumbuhkan disposisi berfikir-kritis tiga mahasiswa pascasarjana Indonesia. Strategi itu direpresentasikan dalam sebuah tabel yang berisi kriteria berfikir-kritis dan fase regulasi diri berfikir-kritis. Strategi tersebut bertujuan untuk menjadikan eksplisit sekaligus melatih metakognisi dan regulasi diri siswa dalam proses berfikir kritis. Nilai yang didapat dari skala disposisi berfikir-kritis menunjukkan bahwa intervensi berhasil meningkatkan disposisi berfikir kritis pada siswa. Sementara itu, interview mengungkap beberapa temuan yang berharga mengenai kesulitan pembelajaran siswa dan bagaimana intervensi telah berhasil membuat siswa menyadari proses berfikirnya disamping, melatih metakognisi dan regulasi diri mereka. Keterbatasan dan implikasi dari strategi ini akan didiskusikan lebih lanjut.
\end{abstract}

Kata kunci: disposisi berfikir kritis, regulasi diri, metakognisi

Abstract. Critical-thinking dispositions are integral to drive and maintain students' use of critical-thinking in their academic and daily life setting. Yet, critical-thinking dispositions have received small attention from researchers. The present study developed and tested a novel strategy aimed to foster three Indonesian Master Students' criticalthinking dispositions. The strategy represented by a table consisting of a set of criticalthinking criteria and phases of critical-thinking self-regulation. The strategy intended to make explicit and to enhance the students' metacognition and self-regulation in the process of critical-thinking. Scores retrieved from critical-thinking dispositions scale shows that the intervention successfully increased the overall students' level of criticalthinking dispositions. The qualitative data from individual interviews revealed some valuable insights about the students' learning difficulties and that the strategy successfully made students aware of their thinking process and reinforced the students' metacognition and self-regulation process. The limitation and implication of the strategy are discussed.

Keywords: critical-thinking dispositions, self-regulation, metacognition 
Nowadays critical thinking has been considered as the foremost goal of education. This notion is supported by two sectors across the globe: university and industry. The former promotes analytical thinking by incorporating critical-thinking into the general rubric for learning assessment (Berniz \& Miller, 2017), and it supports the latter by providing sharp minded graduates. Here, critical thinking serves as a knowledge reinvention catalyst and a main driver for the increase of companies' competitiveness. Both agree with one another that critical thinking is vital for the shape of the future of these two sectors.

According to Facione (1990) critical-thinking dispositions are 'consistent internal motivation to engage problems and make decisions by using critical-thinking' (pp. 65). In other words, critical-thinking dispositions are the fuel and critical-thinking skills is the vehicle. A vehicle cannot transport to a destination without a sufficient amount of fuel. Indeed, the vehicle is important, but, it is difficult to imagine one can be an authentic critical-thinker without possessing appropriate dispositions. Critics have come from employers (Baril, Cunningham, Fordham, Gardner, \& Wolcott, 1998; Cheong, Hill, Fernandez-Chung, \& Leong, 2016; Marie \& Lyndal, 2008). They claim that most universities cannot provide candidates with motivation and skills to apply criticalthinking in the face of today's industrial problems. The challenges are growing but students are not ready to be the answer.

Research supports the employers' claim, reporting that the majority of students are not critical-thinkers, even though they have received years of education for critical-thinking. Some students tend to jump to conclusions (Meletiou-Mavrotheris \& Paparistodemou, 2015), follow their subjective opinions rather than evidence (David, Jelle, Michiel, Theo, \& Milan, 2015), believe in myths (Furnham \& Hughes, 2014), or fail to systematically produce a satisfactory solution for problems (Feinberg, Greenberg, \& Frijters, 2015). Also, being critical can be regarded as harmful in some cultures (Halstead, 2004), thus, people from these contexts may not or even avoid teaching critical-thinking to their students. The students from uncritical cultures may have trouble when studying in an education institution where critical-thinking is highly appreciated. Universities have lowered their admission requirements to attract more international students, however, they are also struggling with meeting the needs of the international students who lack many important academic skills, including critical thinking (Berniz \& Miller, 2017). This is alarming since the number of students in need is rising but universities are not ready to provide sufficient support.

For a long time, scholars have been researching strategies to foster students' criticalthinking dispositions. Most of these strategies were following the philosophical and educationalist tradition of critical-thinking (Abrami et al., 2015; Abrami et al., 2008). One salient common characteristic of these strategies is the emphasis upon argument evaluation and argument production. Despite an ample amount of research to compensate for the weakness of these strategies, recent evidence has shown that these strategies are still inconclusive and produce small gains. These strategies fail because they neglect the vital metacognitive processes of critical-thinking. Critical-thinking is a higher-order thinking process that requires students to be cognizant of their deliberate mental process (Dwyer, Hogan, \& Stewart, 2014). Thus, it is impossible to be critical without thinking about thinking. These strategies were also domain-general in nature. Students often fail to translate these strategies into their various academic tasks. So, students may not find 
these strategies useful nor do they implement these strategies for completing their assignments.

The vacuum of reliable interventions to foster students' critical-thinking dispositions has attracted a significant interest. There is a need to reinvent a new strategy to resolve this issue. One research approach that may help is called design research (Bereiter, 2006; Collins, Joseph, \& Bielaczyc, 2004). This research approach enables a researcher to develop a novel strategy by combining insights derived from previous research.

This study used the design research approach. It proposes and develops a novel criticalthinking strategy to cultivate students' critical-thinking dispositions. The strategy incorporates several theories such as Zimmerman's (2002) self-regulated learning theory, Sternberg's (Sternberg, 1985, 2001, 2015) Successful Intelligence (SI) theory and Schraw's (2001) metacognitive awareness. These three theories provide key principles to explicitly teach critical-thinking: regulation of thinking, thinking with specific goals, and active monitoring of the regulation of thinking to achieve the specific goals.

\section{Theoretical Framework}

This study views critical-thinking as a complex mode of thinking but with one consistent and distinct characteristic. This distinct characteristic is evaluating their thinking process in a circular fashion where they repeatedly revisit and retest their ideas. This characteristic allows them to find biases, flaws, or incoherence and produce actions to resolve these issues. This demonstrates that critical-thinking processes can fit into the self-regulatory model (Zimmerman, 2002) where students continually plan, re-plan, reperform and re-evaluate their thinking until they meet their goals. That is, criticalthinking is a self-regulated thinking process.

Critical thinking requires students to have goals. The goals in the process of criticalthinking are the intended quality of thinking products where students continually visit these criteria to assess their thinking performance. Through these goal-fulfilling actions, students can find whether their thinking has produced the level of critical-thinking they need. However, they often fail to think critically because they do not know what these criteria are to judge the quality of their thinking. The present study incorporates the theory of successful intelligence by Sternberg $(1985,2001,2015)$ as the critical-thinking goals. The rationale of incorporating this theory is that SI allows students to think outside the box by considering beyond analytical thinking (e.g. what is wrong with this?), to practical thinking (e.g. how can I apply this?), creative thinking (e.g. what is the new thing I can offer?), and wisdom (e.g. what can I do to help?). As demonstrated from research, students in SI group overperformed students in a group that focused only to analytical goal (the traditional critical-teaching method) in various lessons and settings (Grigorenko, Jarvin, \& Sternberg, 2002; Sternberg et al., 2014; Sternberg, Torff, \& Grigorenko, 1998). However, these interventions were conducted with mostly white young participants studying in elementary and secondary school in western society. The present study will extend the use of this theory with older group of participants from Asian background, that is Indonesian master students.

To be critical is to be aware upon one's thinking. One hardly accesses critical-thinking if he or she did not aware about his or her own thinking process (Dwyer et al., 2014; Flavell, 1979; Sternberg, 1985). This is where students should have metacognitive 
awareness to produce critical-thinking. According to Schraw (Schraw, 2001), there are two aspects that need to be acknowledged by the students when performing criticalthinking. The two aspects are knowledge of cognition and regulation cognition. These two aspects can be linked to the two previous theories. The SI theory fits into knowledge of cognition, whereas, the self-regulation theory fits into regulation of cognition. Since they are situated in a specific process of critical-thinking, then, the aspects can be named as knowledge of critical-thinking and regulation of critical-thinking. These combinations of interconnected theories generate a novel theoretical framework of metacognitive awareness of critical-thinking, namely extended metacognitive awareness of criticalthinking (EMAF-CT). This framework is illustrated as follow.

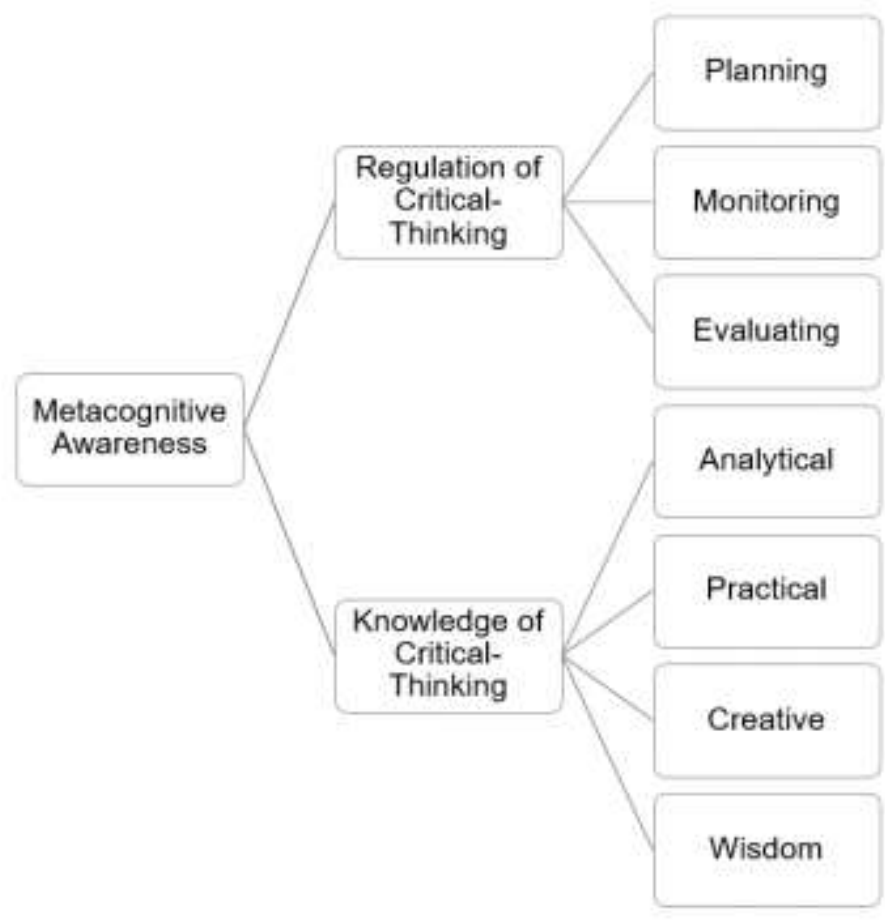

Figure 1. The concept map of Extended Metacognitive Awareness of Critical-Thinking (EMAF-CT)

Overall, the present strategy will incorporate this framework. This framework can accommodate and encompass the complexity of critical-thinking as a repeated evaluation of one's thinking (as in self-regulatory model), production of various goals of thinking (as in SI model) and one's awareness toward two elements of critical-thinking (as in metacognitive awareness model). The combination of these characteristics implies that critical-thinking is largely dispositional rather than acquired cognitive skills since students should be dispositioned to maintain self-regulation and engaged towards achieving the goals of critical-thinking. 


\section{Research Questions and Hypotheses}

\section{Quantitative}

1. Does the CTAT strategy enhance the students' critical thinking dispositions?

H0: CTAT strategy does not enhance the students' critical-thinking dispositions H1: CTAT strategy enhances the students' critical-thinking dispositions?

\section{Qualitative}

2. How does teaching CTAT alter the students' critical-thinking dispositions?

\section{METHOD}

Based on its purpose, this study uses a design research model. According to (Collins et al., 2004), design research is a study where researchers use interconnected diverse theoretical knowledge and various practical information to develop and test the efficacy of a novel intervention approach. As discussed previously, most existing interventions have been proven inconclusive or produced small gains regarding enhancing students' critical-thinking dispositions. Thus, this study aims to present a teaching method to foster students' critical-thinking dispositions.

The present study is also quasi-experimental in design because it tests the strategy in a natural setting where students are subjected to an authentic experience of learning (Cook, Campbell, \& Shadish, 2002). A quasi-experimental study may have greater generalizability than a true-experimental study, however, it is impossible to control confounding factors which may influence the dependent variable. Thus, the degree of confidence about the causal relationship between the intervention and the dependent variable is considerably low. Although this flaw is difficult to resolve, the result of this study can inform the practice of future laboratory experiments.

Three Indonesian master students participated in this study. They were studying Master of Education with different specializations. Two of them were male, one of them was female. The age of the participants was 26, 27 and 31 (Mean=28). They were at semester one, three and four of their studies. In this study, the students will be identified using pseudonyms (John, Angela and Mario).

Understanding the elements and the complexity of critical-thinking as conceptualized in EMAF-CT may help students to be aware and encourage them to regulate their thinking process. However, this means critical-thinking demands a significant amount of mental resources. To reduce the cognitive load when students producing critical-thinking, a table containing columns which address the EMAFT is generated as follow. 
Table 1. The Critical-Thinking Assessment Table (CTAT)

\begin{tabular}{llll}
\hline $\begin{array}{l}\text { Students' Name } \\
\text { Assignment/Date }\end{array}$ & $:$ & \\
\hline No. & Critical-Thinking Aspects & \multicolumn{1}{c}{$\begin{array}{l}\text { Critical-Thinking } \\
\text { Performances }\end{array}$} & Critical-Thinking Actions \\
\hline $1 \quad \begin{array}{l}\text { Analytical } \\
\text { (What is wrong with this? }\end{array}$ & \\
2 & $\begin{array}{l}\text { Practical } \\
\text { (How can I apply this?) }\end{array}$ \\
3 & $\begin{array}{l}\text { Creative } \\
\text { (What is the new thing I } \\
\text { can offer?) }\end{array}$ \\
& $\begin{array}{l}\text { Wisdom } \\
\text { (What can I do to help? }\end{array}$ \\
\hline
\end{tabular}

The table above is called critical-thinking assessment table (CTAT). It reduces students' cognitive load by providing an external memory storage and enables students to activate their extended metacognitive awareness of critical-thinking. Each column has a specific but related function with the other columns. For instance, the first column containing critical-thinking aspects based on SI theory refers to students' critical-thinking goals which students must focus on and compare their writing with these criteria. The next column (critical-thinking performances) is where students put their evaluation of their writing performance based on the criteria presented in the left column. Finally, the last column (critical-thinking actions) contains students' plan of actions to enhance the level of critical-thinking in their writing. The use of these column simultaneously and the use of the table repeatedly may assist students to regulate and improve the critical-thinking in their writing.

For quantitative data, this study administered a critical-thinking dispositions scale at both baseline and post-intervention. The scale is constructed by Sosu (2013). It consists of two dimensions represented by 11 items and each has five response options ranging from 1 as 'strongly disagree' to 5 as 'strongly agree'. The scale dimensions are reflective scepticism and critical openness. The examples of the items are," I often re-evaluate my experiences so that I can learn from them. " and,"I sometimes find a good argument that challenges some of my firmly held beliefs". Sosu (2013) reported in the two stages of the validation study with a total of almost one thousand participants that the critical-thinking dispositions scale has the Cronbach alpha of 0.79 and 0.81 respectively.

For qualitative data, this research used semi-structured interviews. The researcher generates some main open-ended questions to examine the students' experience regarding performing the strategy. Probing questions were asked whenever necessary. The main questions are divided into two phases. For the baseline phase, the questions were: (1) how was your experience of learning critical-thinking at your previous university? (2) What is your definition of critical-thinking? (3) What do you think of the university's attempt to foster your critical-thinking? Whereas for the post-intervention phase, the questions were: (1) how was your experience of implementing the strategy? 
The researcher also recorded the interview using a mobile phone with the students' permission and took notes for some matters that need to probe further with the participants.

This study conducted in three days. The baseline and teaching 1 session were conducted simultaneously on $20^{\text {th }}$ May 2018. After four days, the teaching 2 session was conducted $\left(24^{\text {th }}\right.$ May 2018). The last meeting was on $10^{\text {th }}$ June 2018. The teaching session 3 and the post-intervention scale administrations and interviews were conducted on this day. Two weeks in total was given to the students to use the strategy. The teacher met with the students separately in different hours since they were occupied with classes and assignments. The details of the sessions are as follow.

Table 2. What the teacher/researcher did, and the participants/students did.

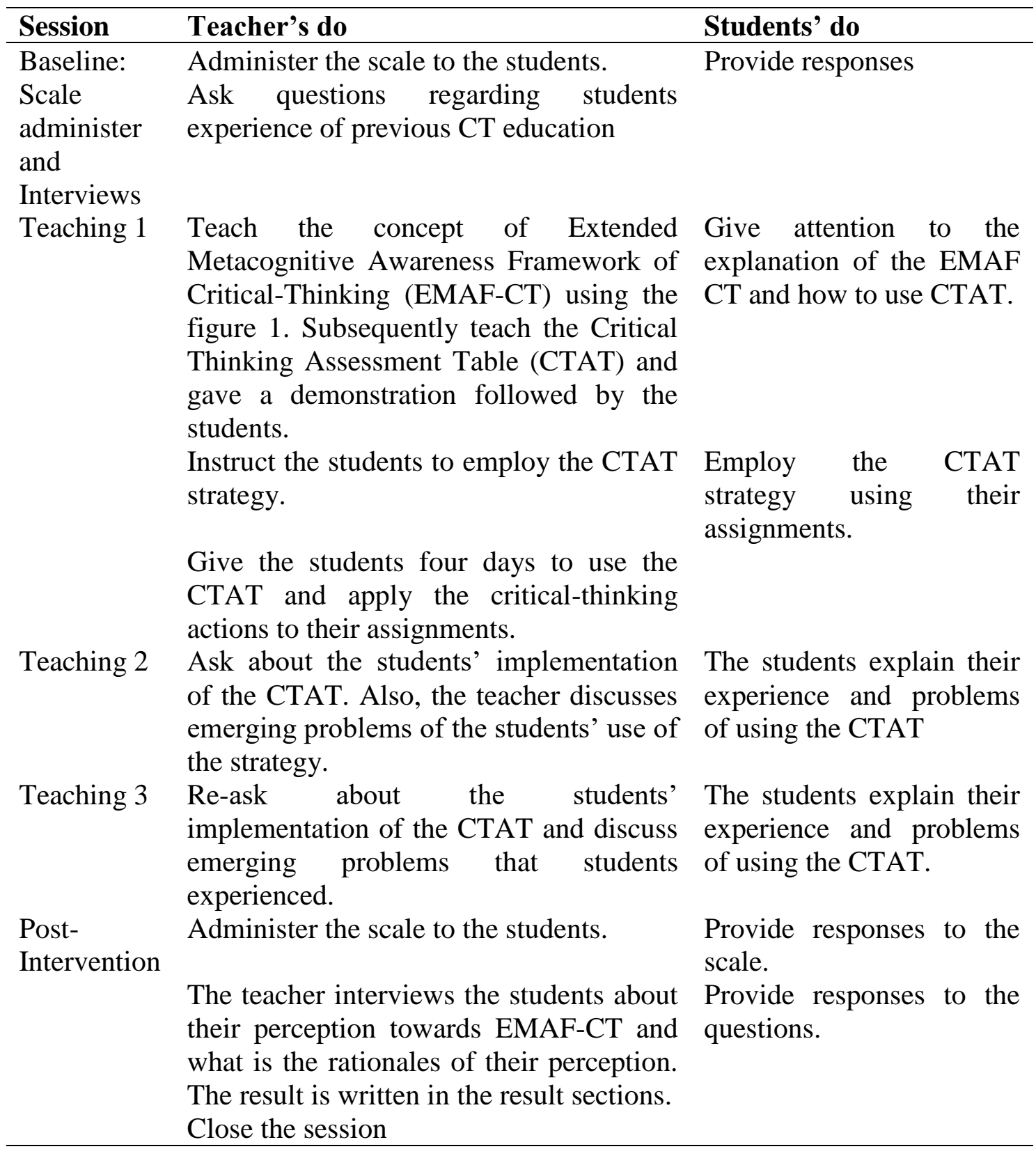


The present study will constrast each students' total score on the dependent variable from baseline to post-intervention. To help the analysis and better read the data, the scores will be transformed into figures. In addition, the score from the scales will be elaborated on using data from the individual interviews. Based on this description, the present study is a mixed-method explanatory design in which the quantitative data is elaborated using the qualitative data. The researcher will transform the transcribed interviews into codes and look for the relationship between the codes. Also, to enhance the depth and the validity of the qualitative data analysis, the saliency analysis will be performed. According to Buetow (2010), saliency analysis is the inclusion of non-recurring but important data in the process of thematic analysis. This means is intended to avoid discarding any significant information that may explain irregularities in the qualitative data.

\section{RESULT}

\section{Quantitative Data}

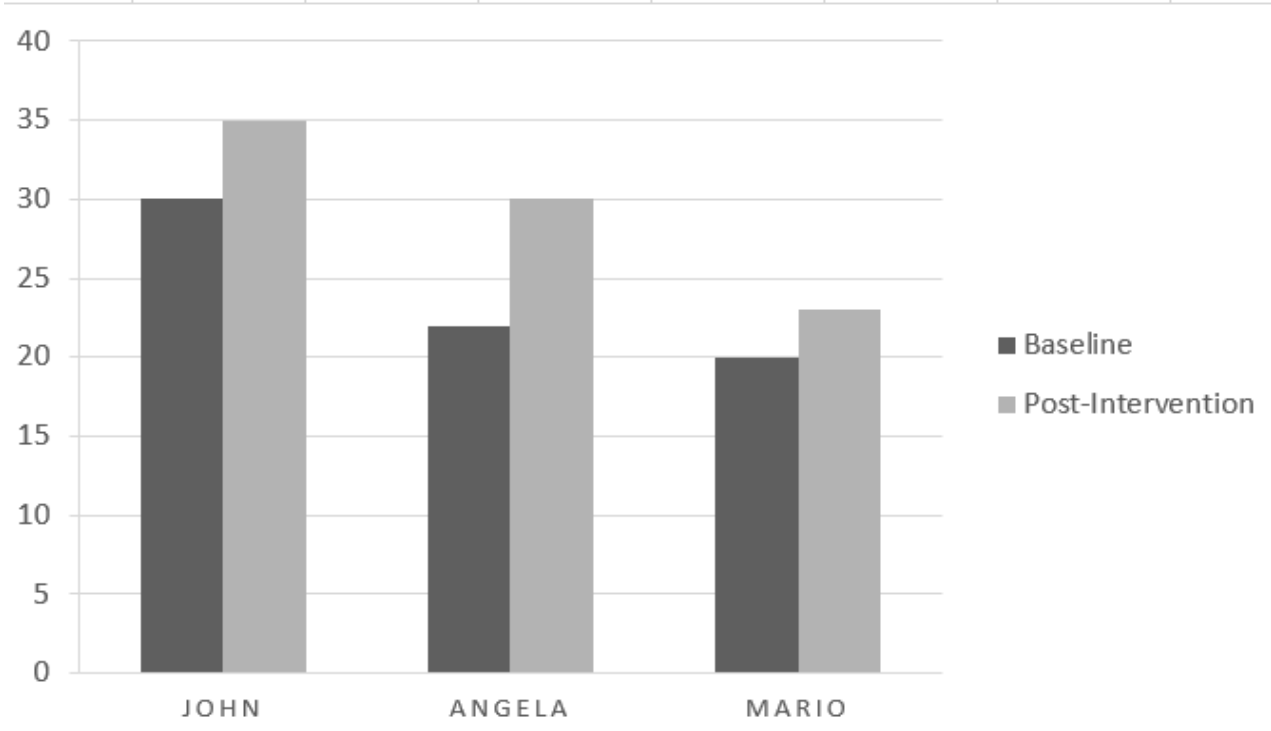

Figure 3. The students' critical-openness scores

Figure 3 shows the students' total scores of critical-openness. As shown in the figure, the total score is generally higher after the intervention compared to baseline. Thus, all the students reported an increase of their reflective skepticism. Although John and Angela reported a large gain by five and eight points respectively, Mario reported a very small gain (three points). 


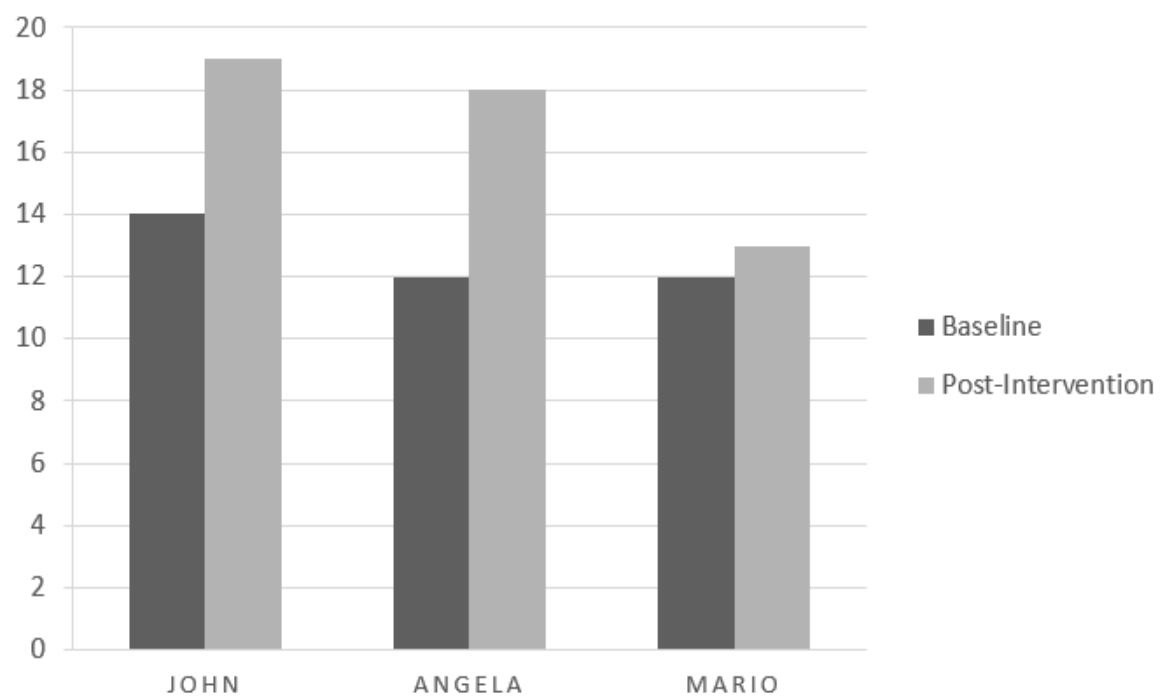

Figure 4. The students' reflective skepticism scores

Figure 4 shows the students' total scores of reflective skepticism. As shown in the figure, the total score is generally higher after the intervention compared to baseline. Thus, all the students reported an increase of their reflective skepticism. Although John and Angela reported a large gain by five and six points respectively, Mario reported a very small gain (one point).

\section{Experience regarding learning $C T$ in previous education}

Of three students, they reported lack of critical-thinking teaching in their undergraduate program. They were not receiving any explicit nor implicit teaching of critical-thinking. Also, in their undergraduate period, the format of assessments was mostly rotememorization where they were measured based on their capacity to recall lessons presented at classrooms and textbooks. It was only when they were working on undergraduate thesis that they were required to implicitly think critically. Of these students, John was the one who believed that he received a better curriculum. He reported that his department also incorporate on-the spot essay format beside multiple choice. However, he argued that he learned CT mostly from his own personal quest of learning. He read books and peer-reviewed journals.

\section{Prior Knowledge regarding $C T$}

Most of the students were having difficulties to explain what critical-thinking is. Their definition of CT was limited to students' capacity to find problems or conflicting ideas in literatures. They believed that $\mathrm{CT}$ is a vague and complex term, but they were satisfied with the definition. However, one of them, John, could expand the definition to students' ability to apply information in a novel context. In John definition, CT was both analytical and practical skill.

\section{Experience of Using the Strategy}

There are three main themes emerged from the qualitative analysis. Firstly, in general, students felt positive about the lesson and they implemented the strategy effectively. 
They belief that the strategy is useful to help them performing critical-thinking in their writing. Secondly, they were specifically interested on the CT's four skills based on Sternberg's SI theory that seems in accordance with their tutor's expectation for assessment of their writing. They stated that CT are complex, but, the elements or it are definable. Also, most students reported that the use of the strategy has helped them to write a more convincing paragraph.

Elaborating from the three themes, for most of the students, the presentation of CT in the metacognition framework were sound logical and the table was easy to use. They reported that the table makes their process of thinking more explicit since they question themselves repeatedly with all aspects of critical-thinking in each paragraph in their assignments. However, in they were having problem to distinguish between practical and creative since their definition or indicator seems overlapping. They often find one paragraph that falls into both practical and creative skill of critical-thinking.

However, there was a minor theme emerged from one of the students. Mario used the table partially. He rather paraphrased many parts of many relevant articles to reduce the writing completion time. Mario believe that critical-thinking is not important, but the final grade/score of his assignment is important. This suggests Mario have performance goal and low level of critical-thinking dispositions.

\section{DISCUSSIONS}

This study is different to previous research which instructed critical-thinking without stimulating the students' metacognitive awareness (i.e. structuring, sequencing and inferencing) (Burbach, Matkin, \& Fritz, 2004; Cargas, Williams, \& Rosenberg, 2017; Marin \& Halpern, 2011; McLean \& Miller, 2010). Also, they put too much emphasis on the mastery of limited reasoning skills. Hence, they did not allow students to be fully critical since they restrict students from being critical in ways that are expected by the tutors. By, contrast our present study facilitated the students' infinite means to creatively generate critical-thinking beyond reasoning skills by allowing them to replan, rewrite and re-evaluate their writing. Moreover, in our study, the students were expected to apply ideas to other contexts, develop novel ideas and provide the positive impacts of their writing. Our study also explored qualitative data to better understanding the effect of the intervention. We examined data at baseline and post-intervention.

There are two issues emerged from the baseline exploration. Firstly, one salient problem amongst the students is their narrow understanding about the definition of criticalthinking. This is similar with the study by Manalo, Kusumi, Koyasu, Michita, and Tanaka (2015). They found that Japanese students are more likely to define criticalthinking as intuitive thinking and positive thinking, whereas, students from New Zealand could define critical-thinking as systematic thinking about uncovering flaws and generating solutions for a presented topic. It shows that Japanese students are limited in their knowledge of cognition about appropriate definition of CT compared to students from New Zealand. Like Japanese students, the Indonesian students in this study provided a very narrow definition of CT. This finding shows the need to address the students' understanding about what critical-thinking is, so they could accurately allocate mental resources in the right direction. 
In their previous undergraduate program, most of the students received no structured course about critical-thinking nor have they received assessments which promote criticalthinking (i.e. essays, projects). Also, the students reported that the existing academic support in the University is inadequate. They find the language support and the academic orientation programs provided too many broad ideas which are difficult to translate into their academic tasks. This finding is pertinent with recent evidence, showing that a general-explicit approach intervention such as universities' common introductory programs has resulted an insignificant effect (Abrami et al., 2015; Abrami et al., 2008; Fong, Kim, Davis, Hoang, \& Kim, 2017; Huber \& Kuncel, 2016). According to students' report, the lessons learned in a general-explicit approach were not applicable and were not relevant to their academic tasks.

Turning now to quantitative data, it is concluded that there was a positive difference between the critical-thinking dispositions levels of the students before and after the teaching and application of the strategy. As expected, the intervention cultivated the students' critical-thinking dispositions as shown by the increase of the critical-thinking dispositions scores. This finding established empirical evidence for the hypothesis that students will have higher critical-thinking dispositions if they regulated and were aware of their critical-thinking process. Also, this finding justifies the extended metacognitive awareness framework of critical-thinking (EMAF-CT).

To understand more about the effect of the intervention, the data from the interviews can provide explanations. Most students in this study conveyed a positive experience when implementing CTAT. To demonstrate, John reported that the table allowed him to critically examine his own writing. John found that the four criteria of critical-thinking derived from theory of successful intelligence were useful for planning various actions to enhance the quality of his writing. He found that the table permitted the exploration of infinite means to revise his writing. He concluded that critical-thinking is certainly beyond just looking for flaws in literatures, but also to offer innovative solutions. John stated that the table is very helpful because it pushed him to think outside the box. This experience built his confidence in performing critical-thinking for his academic tasks. This result is similar to Cargas et al. (2017), who asserted that through the use of explicit reasoning quality rubrics, their students reported a slight increase of critical-thinking skills and dispositions than the baseline scores. Another study by Graham, Harris, and Mason (2005), reported that the positive experience gained from the use of a selfregulation strategy in writing fostered their students' writing self-efficacy. Beyond their studies, our research offers the use of a table to allow students to explicitly elicit their action plans and monitor their metacognitive process in writing critically. The students' recognition of their need to write beyond reasoning may lead the students to be more critically dispositioned individuals.

In the case of Angela, she reported that the EMAF-CT is a very useful piece of knowledge for her. She claimed that the EMAF-CT made her understand what her tutors expect from her. Angela found that the critical-thinking skills in EMAF-CT corresponds with the criteria in the assessment rubrics (topic EDUC 9732). For instance, in the literature review row, the criteria for High Distinction (HD) is, "apply to the topic of the essay and placement of those topics within the broader context of the overall topic". The same with the HD criteria for the method section is, "The design elements are innovative and/or extended in complexity". For Angela, these two criteria showed that her tutor 
expects her to show practical thinking and creative thinking as part of critical-thinking. Beyond this, Angela stated that, "I think I can be analytical, practical, and creative at the same time to get the highest mark". Angela's experiences show that EMAF-CT, particularly the adoption of Successful Intelligence's four critical-thinking skills, matches with the demand of the curricula.

As indicated from the case of John and Angela, the CTAT tackled the two issues (narrow definition of critical-thinking and ineffective strategies for subject-specific tasks) that were discovered in their baseline interviews. Using Sternberg's SI theory, the strategy broadened the students' understanding of what critical-thinking skills are. This action allowed students to incorporate critical-thinking skills other than analytical thinking. The students became more confident to work on their assignment because they finally understood, what John called "the invisible assessment criteria". John added that he realized the reason he cannot get the maximum mark in his previous assignments was because he did not completely understand what his tutors perceive as 'being critical'. The strategy also facilitated the students' production of critical-thinking actions which are relevant for the students' subject-specific tasks. To achieve this, the strategy assisted the students in the process of evaluating, re-planning and monitoring the quality of their writing. As Angela asserted, "The table helped me to be critical to my own writing. To do so, I had to question myself repeatedly: have I performed all four critical-thinking skills?"

However, it was noted that one of the students, namely Mario, reported a very small increase on both dimensions of critical-thinking dispositions and he was reluctant to properly use the CTAT strategy. This could be due to his performance goal. He believed that to achieve a good mark, he just needed to paraphrase from many articles. He claimed that the table "took too much time but with uncertain result". By contrast, paraphrasing a whole paragraph is faster and it is more certain to generate a good mark since the paragraphs come from peer-reviewed international journals. He added that by paraphrasing, he did not have to thoroughly read many articles to still show a decent level of critical-thinking in his assignments. Mario's result indicates that critical-thinking is a cognitive demanding task that requires students to use various resources effectively. Thus, the students' motivation or willingness to perform critical-thinking and to use tools that may help them in critical thinking is key to the success of the intervention. The teaching of critical-thinking strategy can fail when students have low motivation to perform critical-thinking. This evidence supports the report by Cheng and Wan (2017) which found that critical-thinking dispositions are significant moderator between an intervention and the use of critical-thinking skills. This also justifies the need for interventions to encompass students' critical-thinking dispositions. Since the amount of research in critical-thinking dispositions is much fewer compared to research about critical-thinking skills (Abrami et al., 2015; Niu, Behar-Horenstein, \& Garvan, 2013; Samson, 2016), this should provide a strong rationale for researchers to conduct more research about critical-thinking dispositions.

Identifying the narrow conception of critical-thinking skills in previous studies has brought the present study to offer a novel framework. Although the framework informed the shape of the CTAT strategy by providing a broad and more complete set of criteria which corresponds with the students' assessment rubrics, it is possible that the framework (EMAF-CT) is still narrow. Critical-thinking is indeed beyond reasoning 
skills, and encompasses practical, creative and wisdom thinking. However, there may be some others mode of thinking or thinking skills that is out of the reach of the EMAFTCT. Since critical-thinking is inherently cultural and socially constructed, the advance of knowledge in the future could produce a new standard for what critical-thinking is.

The present study is limited in several ways. A small number of participants limits the use of statistical programs to infer whether the difference of the scores was statistically significant. Moreover, as a quasi-experimental study, there were many possible uncontrolled confounding factors that could influence the observed increase in the dependent variable such as other strategy that students used and helps from the learning supports at the university. There is a possibility that the theory and the strategy are not fully connected. This study was a design research which various and related theories were used to generate a new framework of awareness of critical-thinking. The CTAT strategy was derived from this untested framework. These limitations can inform the future study to recruit more participants, and randomly assign participants into control groups.

\section{CONCLUSION AND IMPLICATION}

This study set out to develop a novel strategy to foster students' critical-thinking dispositions. To achieve this goal, the literature was reviewed, and it is found that there is no adequate framework of critical-thinking that relevant with the recent advancement in cognitive research. Thus, a framework namely EMAF-CT was generated, incorporating various relevant theories. This framework became the base of the novel strategy that is called as Critical-Thinking Assessment Table. The strategy is a table containing columns that facilitate students' activation of their metacognition. The finding showed that the strategy could foster the students' critical-thinking dispositions. However, due to the small sample and the natural environment in the study, it is difficult to infer a strong causal relationship between the strategy and the dependent variable. Future study should be conducted in a larger number of participants, control groups and a more controlled setting.

There are some implications to research and teaching of critical-thinking to students. The first implication is there is a need to challenge the existing and dominating concepts of critical-thinking that have been followed by most of research and teaching practice. The present study suggests that critical-thinking is beyond reasoning skills. Tutors should be more explicit about what is their expectations of critical-thinking so the students can operate within these expectations. The second implication is that to teach criticalthinking is to access students' metacognition. Critical-thinking as higher order thinking skill requires students' awareness toward their thinking and elaborated knowledge about what are critical-thinking skills are. This study offers insight of using an extended model of metacognitive awareness in critical-thinking. The models foster both students' knowledge of critical-thinking and their regulating of critical-thinking. Since criticalthinking is a highly cognitive demanding tasks, students' dispositions to incorporate tools that may help them to think critically is vital.

\section{REFERENCES}


Abrami, P. C., Bernard, R. M., Borokhovski, E., Waddington, D. I., Wade, C. A., \& Persson, T. (2015). Strategies for Teaching Students to Think Critically:A MetaAnalysis. Review of Educational Research, 85(2), 275-314. doi:10.3102/0034654314551063

Abrami, P. C., Bernard, R. M., Borokhovski, E., Wade, A., Surkes, M. A., Tamim, R., \& Zhang, D. (2008). Instructional Interventions Affecting Critical Thinking Skills and Dispositions: A Stage 1 Meta-Analysis. Review of Educational Research, 78(4), 1102-1134. doi:10.3102/0034654308326084

Baril, C. P., Cunningham, B. M., Fordham, D. R., Gardner, R. L., \& Wolcott, S. K. (1998). Critical thinking in the public accounting profession: aptitudes and attitudes. Journal of Accounting Education, 16(3), 381-406. doi:https://doi.org/10.1016/S0748-5751(98)00023-2

Bereiter, C. (2006). Design research: The way forward. Education Canada, 46(1), 16-19.

Berniz, K., \& Miller, A. (2017). English language support: A dialogical multi-literacies approach to teaching students from CALD backgrounds. Journal of Pedagogy, 8(2), 101. doi:https://doi.org/10.1515/jped-2017-0011

Buetow, S. (2010). Thematic Analysis and Its Reconceptualization as 'Saliency Analysis'. Journal of Health Services Research \& Policy, 15(2), 123-125. doi:10.1258/jhsrp.2009.009081

Burbach, M. E., Matkin, G. S., \& Fritz, S. M. (2004). Teaching critical thinking in an introductory leadership course utilizing active learning strategies: A confirmatory study. College Student Journal, 38(3).

Cargas, S., Williams, S., \& Rosenberg, M. (2017). An approach to teaching critical thinking across disciplines using performance tasks with a common rubric. Thinking Skills and Creativity, 26, 24-37. doi:https://doi.org/10.1016/j.tsc.2017.05.005

Cheong, K.-C., Hill, C., Fernandez-Chung, R., \& Leong, Y.-C. (2016). Employing the 'unemployable': employer perceptions of Malaysian graduates. Studies in Higher Education, 41(12), 2253-2270.

Collins, A., Joseph, D., \& Bielaczyc, K. (2004). Design Research: Theoretical and Methodological Issues. Journal of the Learning Sciences, 13(1), 15-42. doi:10.1207/s15327809j1s1301_2

Cook, T. D., Campbell, D. T., \& Shadish, W. (2002). Experimental and quasiexperimental designs for generalized causal inference: Houghton Mifflin Boston.

David, B., Jelle, T., Michiel, v. A., Theo, d. V., \& Milan, R. (2015). Self-reported confidence in prescribing skills correlates poorly with assessed competence in fourth-year medical students. The Journal of Clinical Pharmacology, 55(7), 825830. doi:10.1002/jcph.474 
Dwyer, C. P., Hogan, M. J., \& Stewart, I. (2014). An integrated critical thinking framework for the 21st century. Thinking Skills and Creativity, 12, 43-52. doi:https://doi.org/10.1016/j.tsc.2013.12.004

Facione, P. A. (1990). Critical thinking: A statement of expert consensus for purposes of educational assessment and instruction (The Delphi Report).

Feinberg, I., Greenberg, D., \& Frijters, J. (2015). Understanding health information seeking behaviors of adults with low literacy, numeracy, and problem solving skills: Results from the 2012 US PIAAC study: Retrieved from piaacgateway. com website.

Flavell, J. H. (1979). Metacognition and cognitive monitoring: A new area of cognitivedevelopmental inquiry. American psychologist, 34(10), 906. doi:http://dx.doi.org/10.1037/0003-066X.34.10.906

Fong, C. J., Kim, Y., Davis, C. W., Hoang, T., \& Kim, Y. W. (2017). A meta-analysis on critical thinking and community college student achievement. Thinking Skills and Creativity, 26, 71-83. doi:https://doi.org/10.1016/j.tsc.2017.06.002

Furnham, A., \& Hughes, D. J. (2014). Myths and Misconceptions in Popular Psychology:Comparing Psychology Students and the General Public. Teaching of Psychology, 41(3), 256-261. doi:10.1177/0098628314537984

Graham, S., Harris, K. R., \& Mason, L. (2005). Improving the writing performance, knowledge, and self-efficacy of struggling young writers: The effects of selfregulated strategy development. Contemporary Educational Psychology, 30(2), 207-241. doi:https://doi.org/10.1016/j.cedpsych.2004.08.001

Grigorenko, E. L., Jarvin, L., \& Sternberg, R. J. (2002). School-Based Tests of the Triarchic Theory of Intelligence: Three Settings, Three Samples, Three Syllabi. Contemporary Educational Psychology, 27(2), 167-208. doi:https://doi.org/10.1006/ceps.2001.1087

Halstead, M. (2004). An Islamic concept of education. Comparative Education, 40(4), 517-529. doi:10.1080/0305006042000284510

Huber, C. R., \& Kuncel, N. R. (2016). Does College Teach Critical Thinking? A MetaAnalysis. Review of Educational Research, 86(2), 431-468. doi:10.3102/0034654315605917

Manalo, E., Kusumi, T., Koyasu, M., Michita, Y., \& Tanaka, Y. (2015). Do Students from Different Cultures Think Differently about Critical and Other Thinking Skills? In M. Davies \& R. Barnett (Eds.), The Palgrave Handbook of Critical Thinking in Higher Education (pp. 299-316). New York: Palgrave Macmillan US.

Marie, K., \& Lyndal, D. (2008). What skills and attributes does an accounting graduate need? Evidence from student perceptions and employer expectations. Accounting \& Finance, 48(2), 279-300. doi:doi:10.1111/j.1467-629X.2007.00245.x 
Marin, L. M., \& Halpern, D. F. (2011). Pedagogy for developing critical thinking in adolescents: Explicit instruction produces greatest gains. Thinking Skills and Creativity, 6(1), 1-13. doi:https://doi.org/10.1016/j.tsc.2010.08.002

McLean, C. P., \& Miller, N. A. (2010). Changes in critical thinking skills following a course on science and pseudoscience: A quasi-experimental study. Teaching of Psychology, 37(2), 85-90.

Meletiou-Mavrotheris, M., \& Paparistodemou, E. (2015). Developing students' reasoning about samples and sampling in the context of informal inferences. Educational Studies in Mathematics, 88(3), 385-404.

Niu, L., Behar-Horenstein, L. S., \& Garvan, C. W. (2013). Do instructional interventions influence college students' critical thinking skills? A meta-analysis. Educational Research Review, 9, 114-128. doi:https://doi.org/10.1016/j.edurev.2012.12.002

Samson, P. L. (2016). Critical Thinking in Social Work Education: A Research Synthesis. Journal of Social Work Education, 52(2), 147-156. doi:10.1080/10437797.2016.1151270

Schraw, G. (2001). Promoting General Metacognitive Awareness. In H. J. Hartman (Ed.), Metacognition in Learning and Instruction: Theory, Research and Practice (pp. 3-16). Dordrecht: Springer Netherlands.

Sosu, E. M. (2013). The development and psychometric validation of a Critical Thinking Disposition Scale. Thinking Skills and Creativity, 9, 107-119. doi:https://doi.org/10.1016/j.tsc.2012.09.002

Sternberg, R. J. (1985). Beyond IQ: A triarchic theory of human intelligence: CUP Archive.

Sternberg, R. J. (2001). Why Schools Should Teach for Wisdom: The Balance Theory of Wisdom in Educational Settings. Educational Psychologist, 36(4), 227-245. doi:10.1207/S15326985EP3604_2

Sternberg, R. J. (2015). Still Searching for the Zipperump-a-Zoo: A Reflection After 40 Years. Child Development Perspectives, 9(2), 106-110.

Sternberg, R. J., Jarvin, L., Birney, D. P., Naples, A., Stemler, S. E., Newman, T., . . . Grigorenko, E. L. (2014). Testing the theory of successful intelligence in teaching grade 4 language arts, mathematics, and science. Journal of Educational Psychology, 106(3), 881.

Sternberg, R. J., Torff, B., \& Grigorenko, E. L. (1998). Teaching triarchically improves school achievement. Journal of Educational Psychology, 90(3), 374.

Zimmerman, B. J. (2002). Becoming a Self-Regulated Learner: An Overview. Theory Into Practice, 41(2), 64-70. doi:10.1207/s15430421tip4102_2 